\title{
Intellectual Capital and Competitive Advantage of Selected Commercial Banks in Anambra State
}

\author{
Hope Ngozi Nzewi ${ }^{*}$, Eze Ikechukwu Robert ${ }^{2}$, Adani Nnenne Ifechi ${ }^{3}$, Chigozie Patrick Monene ${ }^{4}$, \\ Ohodah Martin ${ }^{5}$ \\ ${ }^{I}$ Department of Business Administration, Nnamdi Azikiwe University, Awka Nigeria \\ ${ }^{2}$ School of Management Technology, Federal University of Technology, Owerri Nigeria \\ ${ }^{3}$ Department of Entrepreneurship, Nnamdi Azikiwe University, Awka Nigeria \\ ${ }^{4}$ Department of Ports Management, Nigeria Maritime University, Okerenkoko, Delta State Nigeria \\ ${ }^{5}$ Department of Management, University of Nigeria, Enugu Campus
}

*Corresponding Author: Hope Ngozi Nzewi, Department of Business Administration, Nnamdi Azikiwe University, Awka Nigeria

\begin{abstract}
The visible bureaucratic bottleneck hindering employees to fully utilize their competencies, skills and abilities in the banks despite the banks persistent recruitment of competent employees necessitated this study. The objective of the study was to determine the relationship that exists between Intellectual Capital and Competitive Advantage of selected Commercial Banks in Anambra State. Survey research design was employed. The population of the study consisted of 100 employees of the selected banks. Data were collected through the use of 5-point Likert scale structured questionnaire. Crombach Alpha reliability test was used to ascertain the level of internal consistency of the instrument. The analysis was done using Simple Regression with Ordinary Least Square Method (OLS) at 5\% level of significance. The result revealed that there is a positive relationship existing between Human Capital and Employee Innovativeness and that a 95\% change in the dependent variable (Employee Innovativeness) was accounted for by changes in the independent variable (Human Capital). It was concluded that human capital has a significant relationship with employee innovativeness. Therefore, we recommend that organizations need to recruit intellectually capable employees and empower them in the organization to utilize their skills and competencies. Besides, there is need to reduce the bureaucratic bottlenecks so as to encourage employees to use their initiatives and discretions to carry out certain aspects of their job.
\end{abstract}

Keywords: Intellectual Capital Competitive Advantage, Human Capital and Employee Innovativeness

\section{INTRODUCTION}

The world of today has gradually moved away from an equipment and machinery dependent world to a more knowledge dependent world. A world where knowledge, skills and ability rule; a knowledge based economy. The importance of knowledge is even more prominent in the service offering sector of the economy where the survival of the firm depends on their employees skill-set and competencies. This is however not to play down its importance in other sectors of the economy. Moradi, Saeedi, Hajizadeh and Mohammadi (2013) posit that in the 21st century, economic success is dependent upon knowledge, innovation and creativity in making new products and offering better service. This brings to the fore the concept of Intellectual Capital (IC) as an important concept. This concept has over the years been capturing much attention in management and other related field of study. IC plays a fundamental role within modern organizations and is part of the foundation of business in the 21st century (Li-Chang\& Chao-Hung, 2010). Thus, in the last decades the strategic management literature has emphasized the crucial role of intangible factors or the intellectual capital as determinants of business competitiveness (Teece, 2000).

IC is a concept that deals with intangible asset and resources possessed either by the organization or its employees. One basic characteristic of these resources is that it is intangible but has been observed by researchers and expert to impact positively on organizations performance and improve their competitive strength. Corroborating this assertion, Nejadirani, Namvar, Rasouli and Yadegari (2012) 
opine that IC has no evident or physical nature and is an intangible asset achieved through employing properties related to human resources, organizational performance, and external relationships. These characteristics are made clear in the various definitions of IC. Sofrain, Tayles and Pike (2008) defines it as the possession of knowledge and experience, professional knowledge and skill, goal relationships, and technological capacities, whose synergic effect can boost firm's performance. It is the combined intangible assets which enable the company to function (Brooking, 1997cited in Ismail \& Karem, 2011). It is a property, which measures an organization's wealth creation capacity (Nejadirani, Namvar, Rasouli\&Yadegari, 2012).

Business especially service firms have moved on from capital dependent to employee skill set and ability dependent. This is also evident in the focused banks in Anambra state. This is possibly the reason they go for the very best while recruiting irrespective of the discipline of the worker. Different aptitude tests, oral and written interviews are conducted all in a bid to ascertain to a greater extent the intellectual quotient of the prospective employee. This is unconnected to the fact that they have seen that their performance and ability to compete favourably in the market place is dependent on the level of skills, knowledge and ability of the employees. Sullivan (2000) states that the business environment has already progressed from the industrial age to the information age were a firm's resources, particularly intangible ones, are more likely to contribute to the firm's attaining and sustaining superior performance. Colombo and Grilli (2005) opine that companies with greater human capital are likely to have better entrepreneurial judgement.Similarly, Lichtenstein and Brush (2001) posit that intangible assets are more important and critical than tangible assets in such a decisive period of the life of a business.

What is bewildering is that despite the focus on intellectual competence of employees during the recruitment stage by employers, when the employees get into the organization, they seem to neglect and sacrifice these abilities, skills, knowledge and competences in the alter of bureaucracy and red tapism; where rules, guidelines, stipulation and regulations rule. They seem not to make maximum use of their human capital by depending mostly on the abilities of top bank official who are few against lower ranking employees probably because the bulk of such employees are employed only on contract basis. These seem to impede the innovative capabilities of employees as their knowledge and skills seem not to be properly harnessed. Andriessen(2004) aligned with this assertion when he posits that one of the main problems of research into IC is the fact that many firms do not explicitly recognise their intangible assets and so do not manage them correctly. It is against this backdrop that this study was necessitated.

\subsection{Statement of the Problem}

The focused banks while recruiting ensure that the best brains in the labour market are recruited. This is done through various examinations and tests to measure the level of knowledge, skills and abilities of the employees. Sometimes, year of experience is an added advantage to the prospective employees. What is however perplexing is that when such employees are finally hired, their abilities, skills, knowledge and competences seem to be neglected. This is unconnected with the level of regulation and regimentation that is prevalent in the banking sectors. This appears to be stifling employees ingenuity, creativity, use of their skills, knowledge and competences. They appear not consulted to make input in making strategic decision and plans. The banks probably rely on top ranking bank officials to make such decision and consulting firms are presumed more knowledgeable than their internal bank skills and knowledge resident in the employees. These skills, knowledge and abilities are sharpened when it is used more often, but when it is neglected as it appears to be in the focused firms. It reduces the ingenuity and innovative tendencies of the employees which if it had been properly harnessed would have been a source of competitive strength and advantage. This problem observed made this study necessary to be undertaken.

\subsection{Objective of the Study}

Broadly, this study seeks to determine the extent of relationship that exists between Intellectual Capital and Competitive Advantage of selected Commercial Banks in Anambra State. Specifically, the study:

a) Seeks to examine the relationship that exists between Human Capital and Employee Innovativeness. 


\subsection{Research Hypothesis}

a) $\mathrm{H}_{\mathrm{A}}$ : Human Capital significantly and positively relates with Employee Innovativeness.

\section{REVIEW OF RELATED LITERATURE}

\subsection{Intellectual Capital}

Intellectual Capital (IC) as a term has no unanimous definition. Over the years, a lot of researchers and authors have viewed it from different perspective. Supporting this claim, Huang, Taylesand and Luther (2010) state that the concept of IC has been defined in multiple ways, resulting in a lack of consensus regarding its definitions and components. It has however gathered momentum despite this seeming shortcoming. The concept was first defined by an economist, John Kenneth Galbraith, in 1969 (Bontis 1998; Edvinsson \& Sullivan 1996; Hsu \& Fang 2009; Huang \& Wu, 2010).

In the different definitions offered by different interests such as researchers, scholars and authors, they have arrived at some general consensus which are that IC is an intangible and multi-dimensional concept/asset held either by the employees or the organization that is capable of enhancing the competitive strength of organizations if harnessed properly. Aligning with this thought, Eren and Kocapinar(2009) posit that despite differences in IC definitions, researchers in this area conclude that it is multi-dimensional in nature, it includes knowledge held by the individual as well as knowledge retained in organisational databases, processes, systems and networks (Youndt, Subramaniam \& Snell, 2004). On their part, Venugopal and Subha (2015) opine that IC is a non-monetary asset without physical existence but possesses value that can generate future earnings. Klein, Crawford and Alchian (1998) argue that it is knowledge, expertise and associated soft assets, rather than their hard physical capital.

IC is associated with knowledge, competencies, skills and abilities either held by employees tacitly or explicitly. It could also be held by the organization in form of processes, networks and relationships. Explicating this further, Sullivan (2000) posits that IC basically constitutes knowledge, lore and innovations. It represents the collective knowledge accumulated in personnel, normal organizational programs, and network relationships of an organization (Nejadirani, Namvar, Rasouli \& Yadegari, 2012). Mouritsen, Larsden and Bukh(2001) view it as the stored knowledge possessed by an organization, which is tacit knowledge, personal knowledge possessed by employees and available to network relationships through interaction.

IC is a concept which for many years has been used as an antecedent to performance and competitive advantage. Researchers and practitioners have recognised that it is a critical resource and a driver for firm sustainable competitiveness (Abdulai, Kwon \& Moon 2012; Roos \& Roos 1997; Youndt, Subramaniam \& Snell 2004), firm performance (Nahapiet \& Ghoshal 1998; Youndt, Subramaniam \& Snell 2004), organisational value creation (Marr, Schiuma \& Neely 2004) and economic growth (Huang \& Liu, 2005).Bontis' (2001) posits that IC is the individual and organizational knowledge that helps to sustainable competitive advantage. In an article titled "Research on Value of Efficiency of Intellectual Capital" Kujansivu and Lönnqvist (2007) opine that IC is critically important for competitiveness of the companies, regardless of the type of the industry.

IC is classified basically into three categories. One classification based on three dimensions has achieved a certain degree of consensus and it includes human capital, structural capital and relational capital (Brennan \& Connell, 2000; Petty and Guthrie 2000; Marr \& Roos, 2005). Suciu(2000)states that as a general perception, intellectual capital has three components: human capital, structural capital and relational capital. This study focuses on Human Capital as a decomposed variable for IC.

\subsection{Human Capital (HC)}

IC has three components but the main component is the Human capital (HC) because it is more critical to the survival of an organization. The primary component of IC is HC (Bontis 1998; Edvinsson \& Sullivan 1996). Hsu and Wang (2012) state that HC is one of the strategic resources critical to firms' success in terms of continuous innovation and existence. Despite being considered as a separate dimension, $\mathrm{HC}$ is recognised by many authors as the organisation's most important intangible resource (Marr \& Roos, 2005) by playing a fundamental role in firms in this new knowledge based economy (Becker, Huselid\& Ulrich, 2001; Edvinsson\& Malone, 1996; Sveiby 1998, 
2000) and being the driving force of the other two components of intellectual capital: relational and structural capital (Fornell, 2000).

HC has to do with knowledge, skills, abilities and competencies possessed by employees. Roos et al (2001) posit that HC is the "competence, skills, and intellectual agility of the individual employees" (p. 23).It is the stock of knowledge, skills, competencies, and abilities embodied in individuals that determine their level of productivity. In principle, it includes innate abilities, and skills acquired through education, training and experience (Medard, Djomo, \&Sikod, 2012).

HC helps in transforming the organization's performance to create value and competitive advantage when properly utilized and harnessed. It is the employees' ability to do things that ultimately make the company work and succeed (Choudhury \& Mishra, 2010). Medard et al (2012) state that it is the stock of competencies, knowledge and personality attributes embodied in the ability to perform labour, so as to produce economic value. It is considered the potential source of innovation and generation of ideas for the firm, thus providing added value of unquestionable importance (Martí, 2001). HC increases as staff accumulate specialized information, skill and know-how (Li-Chang\& Chao-Hung, 2010). This allows them to communicate efficiently and effectively, which reduces decision-making errors, thereby enhancing quality and improving performance (Luthans \& Youssef, 2004). It is an organization's combined human capacity which can find the best solutions for business problems from the knowledge of its individuals (Chen,Zhu \& Xie, 2004).

\subsection{Competitive Advantage}

Competitive advantage has over the years gathered momentum and has become the central theme in strategic management literature. Furrer(2008) posits that the pursuit of competitive advantage is arguably the central theme of the academic field of strategic management. It has to do with the edge an organization has over another that enables it outperform the other competing firms. Wang (2014) states that competitive advantage is obtained when an organisation develops or acquires a set of attributes (or executes actions) that allow it to outperform its competitors.

This edge can be acquired through various means, the knowledge, skills, abilities and competences of employees and organizations which could be seen in the level of creativity and innovativeness of employees is a crucial part of it. Organizations have managed to achieve competitive advantages through proper management of skills and abilities (Nejadirani, Namvar, Rasouli \& Yadegari, 2012).In a knowledge-based economy, the drivers of competitive advantage and organizations consistency are knowledge resources such as creation, storage, dissemination, and application of knowledge assets (Seetharaman, Zaini \& Saravanan, 2002).

As a result of the competitive attributes of intellectual capital, more attention has been paid to intangible assets than tangible assets in service sectors. Authors like Bontis (2002) declare that the current trend is for organisations to focus less on material assets and more on intangible assets when seeking competitive advantages and that those firms with adequate IC have a better chance of survival. Today, the value of IC in the organizations has increased from the small amount estimated in 1990 to USD 15 billion at the beginning of the 21 st century (Nejadirani, Namvar, Rasouli \&Yadegari, 2012).

\subsection{Employee Innovativeness}

Competitive edge can be ascertained in various ways, the ingenuity, innovativeness and creativity of employees form a critical part of it. Innovation may be defined as the act of propagating an idea and transforming it into a new product, service, or business model that can be useful to customers (Souleh, 2014).Innovativeness implies more accessibility to change and more willingness to face new challenges (Skerlavaj, Stemberger, Skrinjar, \&Dimovski, 2007).Tidd, Bessant, and Pavitt (2001) also opine that innovation is not only good thinking, it needs to be realized by action. Therefore, innovation is comprised of original concepts, innovativeness of its members, and real products or services.

The instruments of innovativeness and creativity which impact positively on business performance and a source of competitive edge are derived from the employee's knowledge and thoughts(Moradi, Saeedi, Hajizadeh \& Mohammadi, 2013; Oke, Burke \& Myers, 2004).In this economy the competitiveness of firms is mainly based on their capacity of innovation, and on the management of 
their IC (Souleh, 2014).Innovation has become central to firm competitiveness due to the emergence of the knowledge economy, intense global competition, rapid technological advance and shorter product and technology lifecycles (Dadfar, Dahlgaard, Brege \& Alamirhoor 2013; Lawson \& Samson, 2001).Innovativeness is closely linked to IC and so forms a huge part of competitive advantage component. It is widely accepted that firm's innovation capabilities are more closely linked to their IC than to their fixed assets (Souleh, 2014).The importance of IC for innovation has attracted researchers interested in determining its elements and the process by which enhances the innovative capabilities and performance of firms (Carmen Cabello-Medina et al, 2011).

\subsection{Theoretical Framework}

This study is anchored on the Resource-Based View (RBV) of a firm. The RBV is attributed to Penrose (1959) who posits that the resources possessed, deployed and used by the organisation are really more important than industry structure. The theory has over the years become one of the most influential theoretical frameworks for IC studies (Eisenhardt \& Martin 2000; Kraaijenbrink, Spender \& Groen, 2010). It explains the internal conditions under which competitive advantage for firms is achieved and how that advantage can be sustained over time based on their bundles of resources and capabilities of employees (Barney 1991; Peteraf 1993; Wernerfelt, 1984).

The RBV proposes that firms which possess and control resources that have the attributes that are valuable and rare would obtain competitive advantage and improve performance. However, for these resources to help in gaining competitive edge, it must be inimitable and non-substitutable (Barney, 1991). The theory draws attention and promotes a firm's internal environment as a driver for competitive advantage (Wang, 2014).That is, for resources to be considered capable of promoting competitive advantage and spur performance, it should be tied to competences, abilities, knowledge and employees skill-set. Barney (1991) opines that researchers subscribing to the RBV argue that only strategically important and useful resources and competencies should be viewed as sources of competitive advantage. Strategic assets are difficult to trade and imitate, scarce, appropriable and specialized resources and capabilities like core competencies which are distinctive, rare, valuable firm-level resources that competitors are unable to imitate, substitute or reproduce that bestow the firm's competitive advantage' (Amit \& Shoemaker, 1993; Barney 1991; Prahalad \& Hamel, 1994).

This theory links with this study because it talks about employees skill, knowledge and abilities which are the core components of human capital and it posits that it is these resources that bestow on organization competitive strength and aid performance through making the firm an innovative, creative and learning organization.

\subsection{Empirical Review}

Ogbo, Ezeobi and Ituma (2013) examined the banking sector in Nigeria to examine the effect of intellectual capital on organizational performance. From a population of 7,000 workers in the commercial banks in South Eastern States of Nigeria, a sample of 378 employees of banks was obtained. Chi- Square statistical test was employed in analyzing the data. Findings indicated a notable similar pattern of intellectual capital -organizational performance link as found in Western countries of North America and Europe. Specifically, the finding showed that human capital and structural capital have a positive and significant effect on organizational outcomes in the Nigerian banking sector.

Ekwe (2013) studied the effect of intellectual capitals on employee productivity of banks in developing economies: the Nigeria experience. Data for the study were elicited from the annual reports of six banks (annual reports and accounts of the selected banks in Nigeria spanning from year 2000 to 2011). The collected data were analyzed using longitudinal time series. The hypothesis was tested using multiple regression analysis through the use of SPSS statistical software (version 17.0). From the analysis, it was indicated that there was a positive and significant relationship between components of VAIC and employee productivity of the banks in Nigeria (VIAC coefficient $=1.186$, $\mathrm{R} 2 \mathrm{c}=0.806, \mathrm{R} 2 \mathrm{t}=0.49, \mathrm{P}<0.05)$. From the result stated above, it is thus established that indeed intellectual capital has positive and significant effect on Employee Productivity of banks in Nigeria.

Olunifesi and Bontis (2012) assessed telecommunications companies in Nigerian on managing intellectual capital. The main purpose was to assess how telecommunications companies in Nigeria leverage intellectual capital as a strategic resource for creating competitive advantage. A previously published research instrument was administered and survey data were collected from 320 managers in 
29 telecommunications companies. Results from the analysis showed that Nigerian telecommunications companies have mostly emphasized the use of customer capital, exemplified by market research and customer relationship management to boost their business performance.

Souleh (2014) studied scientific research centres in Algeria in order to examine the impact of human capital management on their innovativeness. The instrument of data collection was through interviews and questionnaire (2011-2013) which were validated through content and construct validity while its reliability was ascertained through Crombach Alpha which was more than .65. Final population of the study consisted of 10 centres with a total of 500 researchers. A convenience sample of 250 researchers was selected through e-mail and postal questionnaires during 2011 to 2013. Data were analyzed with mean and standard deviation using SPSS 18.0 to determine the interaction between the various factors. Results revealed that Human capital management is positively related with the innovativeness of the Centre (70\%), Competency management is positively related with the innovativeness of the Centre (64\%), Knowledge management is positively related with the innovativeness of the Centre (83\%).

Rahayu, Junaini and Tobiagi (2016) used content analysis to examine Intellectual Capital Disclosure practice in the annual report of 12 commercial banks listed on Saudi Arabia (Tadawul) Stock Exchange. The level of efficiency of the studied firms were measured using VAIC indicator which identifies the bank with efficiencies in utilizing the human capital. Ranking of banks according to VAICwere then compared with the traditional way of ranking, to see if the banks with good performance according to traditional ways are also efficient in utilizing capitals. The finding showed that all Saudi banks listed in Tadawul Stock Exchange disclosed intellectual capital information in their 2014 annual report. Intellectual capital items mostly were disclosed in discursive form and throughout the annual report. In terms of average percentage occurrence per intellectual capital for the three categories, human and external capital were closely matched at about 38\% and 35\% respectively, while internal capital was significantly lower at $27 \%$. The results for VAIC efficiency showed that the banks have relatively higher human capital efficiency than structural and capital efficiency.

\section{Methodology}

The study utilized survey research design. The population of the study consists of lower and middles level employees of 10 systematically selected commercial banks within Anambra State which are 100 in numbers (10 each from the individual banks). The data for the study were collected using 5-point Likert scale structured questionnaire. However, before distributing the questionnaire, it was put through Crombach Alpha reliability test to ascertain its level of internal consistency, the coefficient obtained was .890 showing it was reliable. The validity of the instrument was also determined using content validation through the use of experts in the field of Human resources and management. A total of 89 copies of questionnaire were analysed because 7 copies were not returned while 4 copies were improperly filled. The analysis was done using Simple Regression analysis with Ordinary Least Square Method (OLS) at 5\% level of significance.

\subsection{Data Analysis}

\section{Descriptive Statistics}

Table1: Questionnaire on Human Capital and Employee Innovativeness

\begin{tabular}{|l|l|l|l|l|l|l|l|l|}
\hline S/N & \multicolumn{1}{|c|}{ Questionnaire Items } & SA (5) & A (4) & UD (3) & D (2) & SD (1) & X & SD \\
\hline 1 & Human Capital & & & & & & & \\
\hline 2 & $\begin{array}{l}\text { I have the requisite skills to carry out my } \\
\text { duties effectively in my organization. }\end{array}$ & 23 & 46 & - & 20 & - & 3.81 & 1.065 \\
\hline $\begin{array}{l}\text { I am knowledgeable on how to perform my } \\
\text { tasks properly. }\end{array}$ & 30 & 29 & - & 25 & 5 & 3.61 & 1.354 \\
\hline 3 & $\begin{array}{l}\text { My ability has been enhanced through various } \\
\text { training programmes I have attended within } \\
\text { the organization. }\end{array}$ & 12 & 35 & - & 22 & 20 & 2.97 & 1.450 \\
\hline 4 & $\begin{array}{l}\text { I am competent enough to perform well in my } \\
\text { organization. }\end{array}$ & 23 & 33 & - & 14 & 19 & 3.30 & 1.533 \\
\hline 5 & $\begin{array}{l}\text { My organization goes for employees with the } \\
\text { best abilities in the labour market. }\end{array}$ & 12 & 8 & 29 & - & 3.73 & 1.346 \\
\hline
\end{tabular}




\begin{tabular}{|l|l|l|l|l|l|l|l|l|}
\hline & Employee Innovativeness & & & & & \\
\hline 6 & $\begin{array}{l}\text { I am not allowed to show my competence in } \\
\text { my organization. }\end{array}$ & 10 & 22 & - & 21 & 36 & 2.43 & 1.499 \\
\hline 7 & $\begin{array}{l}\text { The rules in the organization prevent } \\
\text { innovativeness from the employees. }\end{array}$ & 21 & 4 & 31 & 14 & 3.00 & 1.446 \\
\hline 8 & $\begin{array}{l}\text { I feel that I have more to offer than the } \\
\text { organization is harnessing. }\end{array}$ & 32 & 39 & - & 18 & - & 3.96 & 1.086 \\
\hline 9 & My ideas are not properly utilized in my firm. & 39 & 21 & - & 29 & - & 3.79 & 1.310 \\
\hline 10 & $\begin{array}{l}\text { My organization appreciates employees with } \\
\text { good skills and abilities. }\end{array}$ & 21 & - & 18 & 21 & 3.12 & 1.558 \\
\hline
\end{tabular}

Source: Field Survey, 2019.

Table2: Regression Output

\begin{tabular}{|l|l|l|l|l|}
\hline \multicolumn{4}{|c|}{ Model Summary } \\
\hline Model & R & R Square & Adjusted R Square & Std. Error of the Estimate \\
\hline 1 & $.976^{\text {a }}$ & .953 & .952 & 1.417 \\
\hline a. Predictors: (Constant), HUMCAP & \\
\hline
\end{tabular}

Source: Field Survey, 2019

Table2: ANOVA Output

\begin{tabular}{|l|l|l|l|l|l|l|}
\hline \multicolumn{7}{|l|}{ ANOVA $^{\text {a }}$} \\
\hline \multicolumn{2}{|l|}{ Model } & Sum of Squares & df & Mean Square & F & Sig. \\
\cline { 2 - 7 } & Regression & 3541.729 & 1 & 3541.729 & 1764.017 & $.000^{\text {b }}$ \\
\cline { 2 - 7 } & Residual & 174.675 & 87 & 2.008 & & \\
\cline { 2 - 7 } & Total & 3716.404 & 88 & & & \\
\hline
\end{tabular}

Source: Field Survey, 2019

Keys: EMPINNO: Employee Innovativeness

HUMCAP: Human Capital

\section{DISCUSSION OF FINDINGS}

From the regression analysis test carried out, it was revealed that there is positive relationship existing between Human Capital and Employee Innovativeness as shown by the correlations coefficient (R) which is shown to be .976 . Further still, it was shown that $95 \%$ change in the dependent variable (Employee Innovativeness) was accounted for by changes in the independent variable (Human Capital) as shown by the Adjusted R Square figure of .952. The model is shown to be statistically significant as revealed by the F which is 1764.017 and Sig value of .000 which is less than .05 level of significance applied in this study. Hence, the alternate hypothesis is accepted and it is said that there is a statistically significant relationship existing between Human Capital and Employee Innovativeness. That is, the more organizations fully utilize the human capital at their disposal, the more the employees will be innovative and this will lead to the organizations gaining competitive edge over the other organizations competing with them for customers or services. This findings is consistent with the findings of Ogbo, Ezeobi and Ituma (2013) who examined the banking sector in Nigeria to examine the effect of intellectual capital on organizational performance and found out that human capital and structural capital have a positive and significant effect on organizational outcomes in the Nigerian banking sector. Similarly, Souleh (2014) who studied scientific research centres in Algeria to examine the impact of human capital management on their innovativeness revealed that Human Capital management is positively related with the innovativeness of the Centre.

\section{CONCLUSION}

Drawing from the findings of the study, it is concluded that human capital has a significant relationship with employee innovativeness. By extension therefore, intellectual capital has a significant effect on competitive advantage of firms. That is, the more organizations stock their establishment with employees that are intellectually capable, the more they acquire competitive advantage over other competing firms in similar industry. 


\section{RECOMMENDATIONS}

Sequel to the findings of this study, it is recommended that:

a) Organizations need to recruit intellectually capable employees and empower them in the organization to utilize their skills and competencies so as to better the performance of the organization.

b) There is need reduce bureaucratic bottlenecks so as to encourage employees to use their initiatives and discretions to carry out certain aspect of their job as this will increase their confidence level and boast their morals.

\section{REFERENCES}

[1] Abdulai, M. S., Kwon, Y.,\& Moon, J.(2012). 'Intellectual Capital and Firm Performance: And Empirical Study of Software Firms in West Africa'. The African Journal of Information Systems, 4(1), 1-30.

[2] Amit, R.,\& Schoemaker, P. J. H.(1993). 'Strategic Assets and Organizational Rent'.Strategic Management Journal, 14, 33-33.

[3] Andriessen, D. (2004). "IC Valuation and Measurement: Classifying the State of the Art." Journal of Intellectual Capital, 5(2), 230-242.

[4] Barney, J. B. (1991). Firm Resources and Sustained Competitive Advantage. Journal of Management, 17(1), 99-120.

[5] Becker, B. E., Huselid, M. A., \& Ulrich, D. (2001). El cuadro de mando de RRHH. Vinculando las personas, la estrategia y el rendimiento de la empresa. Barcelona: Gestión.

[6] Bontis, N. (1998). 'Intellectual Capital: An Exploratory Study That Develops Measures and Models', Management Decision, 36(2), 63-76.

[7] Bontis, N. (2001), "Assessing knowledge assets: a review of the models used to measure Intellectual capital”. International Journal of Management Reviews 3(1), 41-60.

[8] Bontis, N. (2002). There is a price on your head: managing intellectual capital strategically, Business Quarterly, summer, pp.40 - 47.

[9] Brennan, N., \& Connell, B. (2000). Intellectual capital: current issues and policy implications. Article presented at the 23rd Annual Congress of the European Accounting Association, Munich.

[10] Brooking, A. (1997). “Management of intellectual capital.” Long Range Planning, 30(3), 364-365.

[11] Chen, J., Zhu, Z., \& Xie, H.Y. (2004). Measuring Intellectual Capital: a New Model and Empirical Study. Journal of Intellectual Capital, 5, 195-212.

[12] Choudhury,J.,\& Mishra B. B, (2010). "Theoretical and Empirical Investigation of Impact of Developmental HR Configuration on Human Capital Management”. International Business Research, 3(4), 181-186.

[13] Colombo, M. \& L. Grilli (2005). 'Founders' human capital and the growth of new technology-based firms: a compe- tence-based view', Research Policy, 34, 795-816.

[14] Cronbach, L. J. (1951). Coefficient alpha and the internal structure of tests. Psychometrika, 16(3), $297-334$.

[15] Dadfar, H, Dahlgaard, J. J., Brege, S.,\&Alamirhoor, A.(2013). 'Linkage between Organisational Innovation Capability, Product Platform Development and Performance', Total Quality Management, 24(7), 819-834.

[16] Edvinsson, L.,\& Sullivan, P.,(1996). 'Developing a Model for Managing Intellectual Capital', European Management Journal, 14(4), 356-364.

[17] Edvinsson, L., \& Malone, M. S. (1999). El capital intelectual. Cómoidentificar y calcular el valor de los recursos intangibles de suempresa. Barcelona: Gestión 2000.

[18] Eisenhardt, K. M.,\& Martin, J. A.(2000). 'Dynamic Capabilities: What Are They?', Strategic Management Journal, 21, 1105-1121.

[19] Ekwe, M. C (2013). "Effect of intellectual capitals on employee productivity of banks in developing economies: The Nigeria experience". Research Journal of Finance and Accounting 4(11).

[20] Eren, E \& Kocapinar, EB 2009, 'Is Intellectual Capital Antecedent of Entrepreneurship Orientation'. Journal of Global Strategic Management, 6, 121-135.

[21] Hsu, L. C.,\& Wang, C. H.(2012). 'Clarifying the Effect of Intellectual Capital on Performance: The Mediating Role of Dynamic Capability', British Journal of Management, 23(2), 179-205.

[22] Hsu, Y. H.,\& Fang, W.(2009). 'Intellectual Capital and New Product Development Performance: The Mediating Role of Organizational Learning Capability', Technological Forecasting and Social Change, 76(5), 664-677. 
[23] Huang, C. C., Tayles, M.,\& Luther, R.(2010). 'Contingency Factors Influencing the Availability of Internal Intellectual Capital Information', Journal of Financial Reporting and Accounting, 8(1), 4-21.

[24] Huang, C. J.,\& Liu, C. J.,(2005). 'Exploration for the Relationship between Innovation, It and Performance'.Journal of Intellectual Capital, 6(2), 237-252.

[25] Huang, Y. C.,\& Wu, Y. C. J.(2010). 'Intellectual Capital and Knowledge Productivity: The Taiwan Biotech Industry', Management Decision, 48(4), 580-599.

[26] Klein, B., Crawford,R. G.,\& Alchian,A. A. (1998). 'Vertical integration, appropriable rents, and the competitive contracting process'.Journal of Law and Economics, 21, 297-326.

[27] Kraaijenbrink, J., Spender, J. C.,\& Groen, A. J.(2010), 'The Resource-Based View: A Review and Assessment of Its Critiques'.Journal of Management, 36(1), 349-372.

[28] Kujansivu, P.,\&Lonnqvist, A. (2007). Investigating the Value and Efficiency of intellectual capital. Journal of intellectual Capital, 8(2), 272-287.

[29] Lawson, B.,\& Samson, D.(2001). 'Developing Innovation Capability in Organisations: A Dynamic Capabilities Approach'.International Journal of Innovation Management, 5(3), 377-400.

[30] Li-Chang, H.,\& Chao-Hung, W. (2010). Clarifying the Effect of Intellectual Capital on Performance: The Mediating Role of Dynamic Capability. British Journal of Management, 1-27. DOI: 10.1111/j.14678551.2010.00718.x

[31] Lichtenstein, B. M. B., \& Brush, C. G. (2001). How do 'resource bundles' develop and change in new ventures? A dynamic model and longitudinal exploration. Entrepreneurship: Theory and Practice, 25 (3), 37-59.

[32] Likert, R. (1932).A technique for measurement of Attitudes, New York, Archives of Psychology.

[33] Luthans, F.,\& Youssef, C. M.(2004). 'Human, Social, and Now Positive Psychological Capital Management: Investing in People for Competitive Advantage', Organization Dynamics, 33, 143-160.

[34] Marr, B., \& Roos, G. (2005). A Strategy perspective on intellectual capital. In B. Marr (Ed.), Perspective on intellectual capital. Multidisciplinary insights into management, measurement and reporting. Boston: Elsevier.

[35] Medard, N. ,Djomo, J.,\&Sikod, F., (2012). "The Effects of Human Capital on Agricultural Productivity and Farmer's Income in Cameroon”. International Business Research, 5(4), 149-159.

[36] Moradi, M., Saeedi, M., Hajizadeh, H., \&Mohammadi, M. (2013). The Influence of Intellectual Capital on the Improvement of Companies' Financial Performance. International Journal of Economics, Business and Finance. 1(5), 120- 139.

[37] Mouritsen, J., Larsden, H. T.,\& Bukh,P. N. (2005). 'Dealing with the knowledge economy: intellectual capital versus balanced scorecard'.Journal of Intellectual Capital, 6, 8-27.

[38] Nahapiet, J.,\& Ghoshal, S.(1998). 'Social Capital, Intellectual Capital, and the Organizational Advantage'. The Academy of Management Review, 23(2), 242-266.

[39] Nejadirani, F.,Namvar, F. G., Rasouli, R., \& Yadegari, L. M. (2012). Examining the Effects of Intellectual Capitals Management on Organizational Performance: The Case Study. Research Journal of Applied Sciences, Engineering and Technology 4(9), 1040-1050.

[40] Ogbo, A., Ezeobi, J., \& Ituma, A. (2013). Impact of Intellectual Capital on Organisational Peformance: Evidence From Nigeria Banking Sector. Journal of Research in National Development 11(2), 249-254.

[41] Oke, A., Burke, G., \& Myers, A. (2004). Innovation types and their impact on performance in UK SMEs. The 11th proceeding. Cranfield School of Management, Cranfield University

[42] Olunifesi, A.S., \& Bontis, N, (2012). "Managing intellectual capital in Nigerian telecommunications companies", Journal of Intellectual Capital, 13(2), 262 - 282. DOI http://dx.doi.org/10.1108 /1469193121 1225724.

[43] Peteraf, M. A.(1993). 'The Cornerstones of Competitive Advantage', Strategic Management Journal, 14(3), 179-191.

[44] Petty, P.,\& Guthrie, J. (2000), "Intellectual capital literature review: measurement, reporting and management".Journal of Intellectual Capital 1(2), 155-75

[45] Prahalad, C. K., \& Hamel, G. (1994). 'Strategy as a field of study: why search for a new paradigm?' Strategic Management Journal, 15, 5-16.

[46] Rahayu, A. R., Junaini, M,.\& Tobiagi, S. M. (2016). Intellectual Capital Disclosures Practices and Intellectual Capital Performance in Saudi Arabia Financial Institution. Journal of Business Studies Quarterly, 7(4), 1-14.

[47] Roos, G.,\& Roos, J.(1997). 'Measuring Your Company's Intellectual Performance', Long Range Planning, 30(3), 413-426. 
[48] Seetharaman A. B.,Zaini S. H. H. \& Saravanan A. S. (2002). "Intellectual capital accounting and reporting in the knowledge economy." Journal of Intellectual Capital, 3(2), 128-148.

[49] Souleh, S. (2014). The impact of Human Capital Management on the Innovativeness of research Center: The Case of Scientific Research Centers in Algeria. International Journal of Business and Management 2(4), 80-96

[50] Sucio, M. (2000). "Intangible assets and intellectual capital as key factors of romania's convergence", pp 01-43, Available at www.moyak.com/.../knowledge-based-economy.

[51] Sullivan, P. H. (2000). Value-driven Intellectual Capital: How to Convert Intangible Corporate Assets into Market Value, John Wiley \& Sons, Toronto

[52] Sveiby, K. (1998). Measuring Intangibles and Intellectual Capital-An Emerging First Standard, Internet version.

[53] Sveiby, K. (2000). "Intellectual capital and knowledge management", Retrieved from: www.sveiby.com. au/BookContents.html.

[54] Teece, D. J. (2000). Strategies for knowledge assets: the role of the firm structure and industrial context. Long Range Planning, 33(1), 35-54.

[55] Venugopal, D., \& Subha, M. V. (2015). Impact of Intellectual Capital on Corporate Performance.Joint International Conference; Technology, Innovation and Industrial Management, 675-687.

[56] Wang, H. (2014). Theories for competitive advantage. In H. Hasan (Eds.), Being Practical with Theory: A Window into Business Research (pp. 33-43). Wollongong, Australia: Theory. http://eurekaconnection. files.wordpress.com/2014/02/p-33-43-theories- of-competitive-advantage-theori-ebook_finaljan2014v3.pdf.

[57] Wernerfelt, B. (1984). A resource-based view of the firm. Strategic Management Journal., 5(2), 171-180.

[58] Youndt, M. A. Subramaniam, M.,\& Snell, S. A. (2004). "Intellectual capital profiles: An examination of investments and returns," Journal of Management Studies, 41, 335-362.

Citation: Hope Ngozi Nzewi, Eze Ikechukwu Robert, Adani Nnenne Ifechi, e.tal. " Intellectual Capital and Competitive Advantage of Selected Commercial Banks in Anambra State" International Journal of Managerial Studies and Research (IJMSR), vol 7, no. 5, 2019, pp. 27-36. doi: http://dx.doi.org/10.20431/2349-0349. 0705004.

Copyright: (c) 2019 Authors. This is an open-access article distributed under the terms of the Creative Commons Attribution License, which permits unrestricted use, distribution, and reproduction in any medium, provided the original author and source are credited. 